15

\title{
THE STORY OF THE U.S. ROLE IN THE KILLING OF PABLO ESCOBAR
}

\author{
Mark Bowden
}

American military interventions overseas frequently have the inadvertent side effect of mobilizing antiAmerican sentiment. In Vietnam, Somalia, Nicaragua, Afghanistan, Iraq, and elsewhere, the presence of uniformed American soldiers has energized propagandists who portrayed the American effort-including humanitarian missions like the one in Somalia in the early 1990s - as imperialist, an effort to impose Western values or American rule. In some instances, this blowback can severely undermine and even defeat U.S. objectives.

As a result, it is often preferable for interventions to remain covert, even if they are successful. The killing of Colombian drug kingpin Pablo Escobar in 1993 offers a good example of both the virtues and hazards of working undercover with indigenous foreign forces.

This chapter provides background on Pablo Escobar and his Medellin Cartel, including how Escobar achieved notoriety and power in Colombia. It then details Centra Spike, a U.S. Army signals intelligence unit that assisted the National Police of Colombia in finding Escobar and other Colombian drug lords. Although American assistance eventually led to the deaths of Escobar and other drug kingpins, it raised a number of legal and ethical challenges that are discussed in this chapter.

\section{Pablo Escobar and the Colombian drug trade}

During the 1970s and early 1980s, there was an increasing flow of cocaine from Colombia to the United States. A sizeable portion of an American generation reared on smoking dope and dropping acid had matured with an appetite for "uppers" and cocaine, which briefly became fashionable with young white professionals.

Although it was illegal, many considered "coke" harmless fun. A 1981 Time Magazine cover-a far more significant platform at the time than now-featured a martini glass filled with the white powder. ${ }^{1}$ The Time Magazine story sounded all the right alarms about the drug's addictive properties, but it also described coke as "an emblem of wealth and status" and "the all-American drug." Beginning in 1984, the popular television series Miami Vice outfitted law enforcement battles with drug traffickers with sleek speedboats and, stylizing the violence, draped its settings and characters in shades of cool pastel, glamorizing the growing illicit enterprise.

Along with Colombia's other rich traffickers, Pablo Escobar, head of the Medellin Cartel, had become a person of interest to U.S. authorities during the Ronald Reagan administration. Escobar was a celebrated figure in Colombia, which had at best an ambivalent attitude toward drug trafficking. No matter 
how much the U.S. government wanted to stop it, cocaine had been a tremendous boon to Colombia's economy. The tide of American dollars had employed thousands, enriched whole communities, and lifted many to positions of power.

This growth of opportunity weighed heavily against the violence of narco-traffickers, who frequently warred against each other and the police. Escobar's policy of plato o plamo (silver or lead) either frightened or "bought" many police officers and judges. ${ }^{3}$ Authorities largely tolerated his illicit business. His infamy, wealth, and status grew. At his cartel's height, Escobar would be ranked as the seventh richest man in the world by Forbes. ${ }^{4}$

Escobar cultivated popular support in Medellin, a major Colombian city, by building housing for the poor and investing in soccer clubs and stadiums. These efforts, along with his personal charm, led to his election first to the city's governing council and then as an alternate to the Camara de Representantes (House of Representatives of Colombia). ${ }^{5}$ Escobar was just getting started. He had ambitions to be president and to turn Colombia into a narco state.

Yet then came crack, cocaine's cheaper, street version, which triggered an epidemic of addiction, violence, and crime in the United States. The drug lost its cool and became a serious problem. In April 1983, U.S. Ambassador to Colombia Lewis Tambs made curbing cocaine trafficking his number-one priority, and American pressure started to change the climate in Bogota. ${ }^{6}$ When Representative Pablo Escobar tried to take his seat in El Congreso (Congress of Colombia), he was publicly confronted by its leaders, called out as a thug, and effectively chased from its halls. ${ }^{7}$ Insulted and outcast, Escobar was from that day forward at war with the state.

Although the government of Colombia was now officially committed to bringing Escobar to justice, it was not yet ready to invite its American allies into the fight. The country was reluctant to concede that it needed American help to police its own country, so Americans were mostly on the sidelines during the bloody war that raged in the 1980s. During this war, Escobar and his allies killed politicians, judges, journalists, and others who criticized him, which contributed to Medellin becoming one of the most violent cities in the world at the time.

In 1989, Escobar's men assassinated Luis Galan, the front-runner in the Colombian presidential race (and an outspoken enemy of the narcos). ${ }^{8}$ Then, in a failed attempt to kill Galan's successor, Cesar Gaviria, they downed an Avianca airliner, killing 110 people. ${ }^{9}$ Gaviria had been warned and skipped the flight. $\mathrm{He}$ was subsequently elected president. ${ }^{10}$ Bombing the plane was not even the worst of Escobar's atrocities during those bloody years, but it did give the U.S. government the opening it needed to step directly into the fight.

The downing of the Avianca flight came a year after the terrorist attack on Pan Am Flight 103 over Lockerbie, Scotland. In the wake of the Pan Am attack, the United States and other world powers elevated threats to air travel as a primary concern. Despite the importance of international air travel, it remained vulnerable to terrorism. The global counterterrorism community prioritized deterring and punishing any actor who would target commercial airliners.

Two Americans were among those killed on the Avianca flight. As a result, the George H.W. Bush administration viewed Pablo Escobar, José Rodríguez Gacha, and other cartel leaders as direct threats to U.S. citizens. Weeks after the Avianca bombing, President Bush released an opinion by the U.S. Justice Department's Office of Legal Counsel concluding that it would not violate the Posse Comitatus Act for the U.S. military to be employed against criminal suspects overseas. ${ }^{11}$ From the perspective of the Bush administration, the narcos could now be legally killed.

The following year, in 1990, worries about the Medellin Cartel grew even greater when some of Escobar's men attempted to buy 120 Stinger anti-aircraft missiles and other military hardware in Florida. As stated by the Washington Post at the time,

The two Colombian nationals, one allegedly associated with cartel chief Pablo Escobar, were charged with offering undercover agents more than $\$ 1$ million in cash in exchange for Stingers, 
M-16 automatic rifles, night-vision goggles and other weaponry that was to be stolen from U.S. military bases. ${ }^{12}$

Mindful of Executive Orders dating back to 1976 prohibiting the U.S. government from assassinating foreign citizens, President Bush ordered a clarification, which was drafted by the Defense Department counsel:

[The Order's] intent was not to limit lawful self defense options against legitimate threats to the national security of the United States or individual U.S. citizens. Acting consistent with the Charter of the United Nations, a decision by the president to employ clandestine, low visibility or overt military force would not constitute assassination if the U.S. military forces were employed against the combatant forces of another nation, a guerrilla force, or a terrorist or other organization whose actions pose a threat to the security of the United States. ${ }^{13}$

The U.S. military could now target Escobar and other Colombian drug lords. It still had to work with the government of Colombia, however, which in 1989 held a dim view of the American military operating within its borders. Newly elected President Gaviria nevertheless allowed a covert U.S. Army signals intelligence unit to help Colombian police track the narcos down. It was code-named Centra Spike.

\section{Centra Spike}

Centra Spike's primary purpose was to find people, although it was designed to offer an array of support intelligence. By eavesdropping on radio and telephone conversations from the air, Centra Spike's members could pinpoint the origin of a radio or cell phone call within a few hundred meters in seconds. It was incredibly accurate.

As described in this author's book Killing Pablo:

What was more remarkable was the electronic package now used to accomplish that feat. Instead of triangulating from three receivers on the ground, they did it from one small aircraft. The airborne equipment substituted the three separate ground locations by taking readings from different points along the plane's flight path. As soon as a target signal was received, the pilot would begin flying an arc around it. Using computers to do precise, instantaneous calculations, they were able to begin triangulating off points in that arc within seconds. If the aircraft had time to complete a half circle around the signal, the location of its origin would be known to within two hundred meters. This could be done regardless of weather conditions or preventative measures taken by targets on the ground. Even a coded radio signal could not disguise its point of origin. ${ }^{14}$

President Gaviria had recruited Colonel Hugo Martinez to head the Colombian National Police's Bloque de busqueda (Search Bloc), a special unit devoted to finding, arresting, or killing the country's top narcos. ${ }^{15}$ The problem, of course, was finding them. Escobar had nearly unlimited resources, and he also had many friends in the country. Many Colombians perceived him as a Robin Hood figure, given his financial spending in his home city to win support during his election campaigns.

Escobar had also cloaked his cause in the Colombian flag, accusing President Gaviria and Colonel Martinez of selling out to the United States. He turned the issue of extradition into a nationalist cause. Aware that the Colombian judiciary had been intimidated and corrupted, Washington pressed for top narcos to be flown to the United States for trial and imprisonment. Escobar rightly saw extradition as the end of the line for him, so he rallied public support behind banning the practice, which he characterized as an insult 
to Colombia's sovereignty. The argument was popular enough that some Colombians helped hide Escobar or tipped him off when the Search Bloc planned a raid.

The advantage of Centra Spike was that the unit's presence was all but invisible, and its capabilities generally unknown. Additionally, Centra Spike's eavesdropping process was not what Colombians might expect from a state-of-the-art American listening operation. As explained in Killing Pablo,

Anyone looking for America's most sophisticated eavesdropping equipment would be watching for something high-flying and fancy, something with great bulbous features on the top or bottom, probably bristling with antennae. They wouldn't be searching for two perfectly ordinary-looking Beechcraft, an older model 300 and a newer $350 .{ }^{16}$

On both the inside and outside of the Beechcraft, they appeared as standard two-propeller commercial planes, no different from what charter services or major companies would use to transport their executives. ${ }^{17}$ Transport via aircraft was common in a country such as Colombia, which had many unreliable mountain roads.

The Beechcraft, of course, were not standard. They were $\$ 50$-million spy planes outfitted with sophisticated, state-of-the-art electronic eavesdropping and direction-locating equipment. ${ }^{18}$ As stated in Killing Pablo,

If someone looked very closely - for instance, with a tape measure - they would discover the Beechcrafts' wing-spans to be about six inches longer than that of the normal models, because the plane's two main eavesdropping antennae were installed inside. Five more antennae could be lowered from the belly of the plane once it was in flight. Inside, until they took off, the planes looked like standard models. Centra Spike's operators would board carrying laptop computers, and set up for listening only after the plane had reached an altitude of twenty to twenty-five thousand feet. Then antennae would be lowered, panels folded down from the inner walls, and the computers plugged into the plane's mainframe and power center. The two operators wore headsets with earphones, one in each ear, so they could monitor four frequencies simultaneously. The computer screens before them displayed graphically the plane's position and the estimated position of the signals they locked on to. Since the plane flew so high and could listen through cloud cover, there was no tip-off below. ${ }^{19}$

Another incredible capability of Centra Spike was that the team could power on a cell phone remotely, provided that the battery was left in the phone. ${ }^{20}$ The phone could be activated to emit a low-intensity signal, enough for the unit to acquire its general location, without activating the phone's lights or sound. Centra Spike operators would generally power on a phone when the target was likely sleeping, then position the aircraft into position to monitor any phone calls the target might make when they awoke.

Over the early months of 1990, Centra Spike armed Colonel Martinez with critical information concerning the whereabouts of the narco kingpins and also the structure of their organizations. Charting the pattern of Medellin Cartel phone calls, the unit could draw maps of the organization's inner workings, its links not only with Escobar's inner circle and criminal enterprises but with the network of bankers, accountants, lawyers, and other "civilian" associates who managed its investments, accounts, and payrolls.

It became increasingly hazardous, legally speaking, for anyone supporting Escobar to conceal their activities. By the end of 1990, Escobar's once-comfortable life had turned into a nightmare. He was on the run constantly, often escaping minutes before the Search Bloc swept through his latest hideout. Increasingly desperate, Escobar found a new way to pressure President Gaviria. Colombian politics had always been dominated by an incestuous group of affluent families centered in Bogota. He began kidnapping the sons and daughters of some of the nation's preeminent families, threatening to kill them-at times making good on the threat. ${ }^{21}$ 
He demanded that Gaviria back off the pursuit and promise to never extradite him to the United States and in return offered to negotiate a compromise. Under tremendous pressure from some of his most powerful friends, and desperate to lower the level of violence in Colombia, Gaviria finally ignored the entreaties of U.S. Ambassador Tambs and struck a deal with Escobar in 1991.22

In return for a promise that he would not be extradited, Escobar agreed to surrender. ${ }^{23}$ The murders and kidnappings would cease. He would plead guilty to one relatively minor crime-acting as a middleman in a single drug deal — and serve a short term in a prison on a hilltop outside Medellin that Escobar had built himself and for which he had hired all of the guards. ${ }^{24}$ The Colombian National Police were not allowed to even approach this sanctuary, which Escobar had furnished with every luxury.

As infuriating as the deal was, Gaviria hoped that his prosecutors would be able to find new charges against Escobar that would eventually lock him up in a real prison permanently. It did not play out that way. Escobar continued to manage his business from his cushy jail cell. He frequently made trips into Medellin, even appearing at soccer matches and waving to the crowd.

For the most part, Colombian authorities looked the other way, but when Escobar began executing members of his organization inside the prison whom he suspected of stealing from him, it was too much for even Gaviria to stomach. As authorities moved in to arrest Escobar and transfer him to a real prison in July 1992, he escaped and resumed his life on the run. ${ }^{25}$

Having tried and failed to strike a deal with Escobar, Gaviria now abandoned his concerns about Colombian sovereignty. Centra Spike returned to the country and resumed hunting. This time it came with a squadron of Delta Force Special Operations Forces.

\section{U.S. Special Operations Forces join Centra Spike}

The melding of this American special operations unit and the Colombian National Police did not go smoothly at first. Due to some cultural missteps, the Delta role was pared down. Left behind were a small number of Delta personnel who could speak Spanish fluently and who were better suited temperamentally to manage the tricky partnership. ${ }^{26}$

Colonel Martinez and his men had suffered a great deal in their pursuit of Escobar, and they resented the idea that a crack American military unit had arrived to show them how to do their job more effectively. ${ }^{27}$ Yet they were willing to concede that catching Escobar, who always seemed to stay one step ahead, would require not only Centra Spike's magic but a mobile strike force capable of reacting swiftly and securely when new targeting information arrived. This was Delta's specialty.

In short order, Escobar's world got smaller. Delta worked closely with the Search Bloc, improving its reaction time and tactics. ${ }^{28}$ Steered in part by intelligence from Centra Spike, the Search Bloc kept closing the ring around Escobar. Nevertheless, even as cooperation improved, problems arose. It is hard to tie the hands of skilled soldiers engaged in dangerous work thousands of kilometers from home. In theory, American personnel were barred from participating in raids, but the line between advising and acting began to blur.

The Search Bloc's methods were also problematic. In June 1990, the Search Bloc killed John Arías, one of Escobar's most trusted sicario (hitman) leaders. ${ }^{29}$ One month later, the Search Bloc captured Hernan Henao, Escobar's brother-in-law and a trusted associate. ${ }^{30}$ Then, on August 9, they killed Escobar's longtime partner in crime Gustavo Gaviria, his cousin and friend from his first days of skipping school and stealing cars. ${ }^{31}$ The Search Bloc claimed Gaviria was killed in a shoot-out, yet the expression "killed in a shoot-out with police" was regarded as a euphemism for summary execution.

Escobar claimed that there had been no shoot-out, that his cousin had been captured, tortured, and then executed by Colonel Martinez's men. These two losses deeply affected Escobar both emotionally and professionally: Henao had been the cartel's treasurer and main moneyman, and Gustavo had been one of Escobar's most trusted confidants. ${ }^{32}$ 
It was easy to rationalize these abuses. Escobar authored many atrocities. The Colombian National Police had borne the brunt of his violence for years and were inclined to meet fire with fire. The scale of the narco's threat to Colombia had long ago transcended law enforcement. This was war, and Escobar was a threat to the state. Yet American involvement in these aggressive tactics undermined basic moral and legal principles.

\section{Legal and ethical challenges grow}

A bigger problem soon arose with the appearance of Los Pepes (Perseguidos por Pablo Escobar, or People Persecuted by Pablo Escobar), an anti-Escobar death squad that began targeting even non-criminal associates, including Escobar's wife and children, extended family members, lawyers, bankers, and accountants.

In one case, the teenage son of a lawyer who had represented Escobar was slain with his father. ${ }^{33}$ Los Pepes members were supposedly composed of family members of those who had been killed by Escobar and his men. This encompassed a large group of people, including the wealthy, government and industry figures, policemen (including members of the Search Bloc itself), and, notably, members of rival criminal cartels. This partnered the Search Bloc with known criminals and implicated it in extrajudicial killings.

Clearly a violation of U.S. policy, there was not adequate pressure to curb these excesses. Although Los Pepes' actions were immoral and illegal, they were effective, and U.S. personnel in Bogota expended little effort to stop them. A U.S. Drug Enforcement Administration cable from the period pointed out:

The attacks by Los Pepes further demonstrate their resolve to violently retaliate against Escobar each and every time Escobar commits a terrorist attack against the [Government of Colombia] and/or the innocent citizens of Colombia. Although the actions are not condoned nor approved by the [Colombian National Police] nor the [U.S. Embassy] they may persuade Escobar to curb such behavior for fear of losing members of his own family. Too, these types of attacks will seriously cut into those assets owned by Escobar and his associates. ${ }^{34}$

Escobar complained bitterly about the tactics used against him, even though he recognized no legal or moral limits to his own actions. Los Pepes were merciless, often signing its handiwork by draping crudely lettered signs around the necks of its victims with taunting messages for Escobar. ${ }^{35}$ If the Search Bloc had for years been trying to pluck Escobar from the top of his mountain of personal and business associates without success, this new more determined effort was taking down the mountain itself.

The institutional charts generated by Centra Spike's surveillance-which not only mapped Escobar's personal and business ties but which could pinpoint the location of most people on it - was clearly being employed to devastating effect. As stated in Killing Pablo,

Up in their vault at the embassy, Centra Spike analysts weren't missing the distinct pattern in Los Pepes' hits. The death squad was killing off the secret white-collar infrastructure of Pablo's organization, targeting his money launderers, bankers, lawyers, and extended family, as if using the very charts that Centra Spike and the CIA had painstakingly assembled over the previous six months. ${ }^{36}$

In fact, Los Pepes' hits were often correlated with new targeting information that Centra Spike turned over to CIA Chief of Station Bill Wagner, who then provided that information to the Search Bloc. Even more instructive was whom Los Pepes chose not to kill. As explained in Killing Pablo,

There were certain key individuals in Pablo's inner circle who were monitored constantly by the Americans, often with video as well as audio surveillance. Not only were these people key to 
intelligence gathering, but anyone paying them a visit, threatening them, or killing them would likely show up in the American monitoring. These were the people Los Pepes left alone. ${ }^{37}$

Providing intelligence that would later be used to assist a murder - such as supplying the street address of a target who was subsequently killed - seemed to be in violation of Executive Order 12333, which stated: "No person employed by or acting on behalf of the United States Government shall engage in, or conspire to engage in, assassination." ${ }^{38}$ The Americans in Bogota were generally unwilling to risk their careers and freedom on the legal opinion issued by the Defense Department's legal counsel in 1989. As a result, they acted carefully on intelligence they collected. Major Steve Jacoby turned his Centra Spike intelligence over to Wagner; how that intelligence was later acted on was, as far as Jacoby was concerned, outside of his purview. ${ }^{39}$

Wagner supplied the Colombian government the intelligence he thought would be the most useful, but an unofficial channel also existed. The complete daily intelligence reports were kept in a red book that could be checked out by official U.S. Embassy visitors. Colombian police officers visited the embassy regularly. ${ }^{40}$

The link was clear enough that the new U.S. ambassador in Bogota, Morris Busby, cabled his concerns to Washington in August 1993, after Colombia's attorney general, Gustavo de Grieff, threatened to expose it (referring to himself in the third person):

The [Government of Colombia] has long been worried that police officials may have been cooperating with Los Pepes, and that [a Colombian official] has now told Ambassador Busby that he has new, "very good" evidence linking key members of the police task force in Medellin charged with capturing Pablo Escobar to criminal activities and human rights abuses committed by Los Pepes. Our own reporting since early February has also suggested that the police were cooperating with the group at some level, including sharing information. ${ }^{41}$

The methods crossed moral and legal boundaries, but they worked. By late 1993, Escobar had grown completely isolated. He was hiding with one bodyguard in a small house in Los Olivos, a neighborhood in Medellin, cut off from money and allies. The one link he retained was a satellite phone connection to his wife and children, which he used regularly even though he was now aware those hunting him could use the signal to track his location.

He was ordinarily careful to keep his conversations short and often made calls while being driven around Medellin in a taxi. Yet in a long conversation with his son on December 2, 1993, Escobar neglected his usual precautions. His location was pinpointed to a specific neighborhood, and using an Americanprovided portable locating device, the Search Bloc identified it precisely. Colonel Martinez's men closed in, and the Search Bloc gunned down both Escobar and his bodyguard as they attempted to flee the house across a back roof. ${ }^{42}$

Officially, Search Bloc shots fired from a distance felled Escobar. He was hit three times. The shot that killed him cleanly entered his right ear and passed directly through his brain. It was either administered as a coup de grace after he fell, or, as one of the Delta Force operators told this author, "It was some pretty nice shootin'., 43

\section{Conclusion}

The role played by Centra Spike and Delta Force in the successful hunt for Pablo Escobar was not fully revealed until years later, when Killing Pablo was published in 2001. While Escobar himself complained repeatedly that Americans were behind the effort, the U.S. military role was kept quiet to the point that it 
never colored the Search Bloc's efforts. The hunt was seen strictly as a Colombian National Police operation. Secrecy enabled President Gaviria to avoid the embarrassment and political repercussions he might have faced if it were known that he had invited American military forces to operate inside his own country. In that sense, it was a complete success.

The success, however, came at a cost that the U.S. military is duty-bound to avoid. Working closely with a foreign military force (in Colombia, the National Police function as a branch of the military) with looser standards than its own implicated U.S. soldiers in operations that violated American ethical and legal constraints. In some cases, innocent people were targeted and killed.

It will never be known if Pablo Escobar could have been brought to justice without these tactics, but it is likely he would have. It might just have taken longer, but it would have been for good reason: the U.S. military is held to higher standards than those in many other countries and certainly higher than those employed by criminal organizations.

\section{Notes}

1 Michael Demarest, “Cocaine: Middle Class High,” Time, July 6, 1981, http://content.time.com/time/magazine/ article/0,9171,922619,00.html.

2 Ibid.

3 Patrick L. Clawson and Rensselaer W. Lee III, The Andean Cocaine Industry (New York: Pallgrave Macmillan, 1996), 51; Simon Strong, Whitewash: Pablo Escobar and the Cocaine Wars (London: Pan Books, 1996), 34-65.

4 Amanda Macias, "10 Facts Reveal the Absurdity of Pablo Escobar's Wealth," Independent, December 29, 2017, www.independent.co.uk/news/people/pablo-escobar-worth-wealth-money-how-much-a8133141.html.

5 Robert D. McFadden, "Head of Medellin Cartel Is Killed by Troops in Colombia," New York Times, December 3, 1993, www.nytimes.com/1993/12/03/world/head-of-medellin-cocaine-cartel-is-killed-by-troops-in-colombia. html.

6 Alan Riding, "Shaken Colombia Acts at Last on Drugs," New York Times, September 11, 1984, www.nytimes. com/1984/09/11/world/shaken-colombia-acts-at-last-on-drugs.html.

7 McFadden, "Head of Medellin Cartel Is Killed."

8 Christine Armario, "Pablo Escobar's Hit Man, Known as 'Popeye,' Dies of Cancer," Associated Press, February 6, 2020, https://apnews.com/article/9435a29de481dd47f8c73c1e42899d8b.

9 Chris Dyer, "That Bomb as a Work of Art," Daily Mail, December 27, 2018, www.dailymail.co.uk/news/article-6532649/Pablo-Escobars-hitman-Jhon-Jairo-Vasquez-tells-blew-airliner-killing-110-people.html.

10 Ibid.

11 Michael Isikoff and Patrick E. Tyler, "U.S. Military Given Foreign Arrest Powers," Washington Post, December 16, 1989, www.washingtonpost.com/archive/politics/1989/12/16/us-military-given-foreign-arrest-powers/9ff56a099271-4778-ae99-03c60b3b1f0b/.

12 Michael Isikoff, "2 Colombians Held in Missile Scheme," Washington Post, May 8, 1990, www.washingtonpost.com/ archive/politics/1990/05/08/2-colombians-held-in-missile-scheme/f80616f7-03fc-4b44-b566-9ca2c01c7c18/.

13 Office of the Judge Advocate General of the Army, "Memorandum of Law: Executive Order 12333 and Assassination" (official memorandum, Washington, DC: Department of the Army, November 2, 1989).

14 Mark Bowden, Killing Pablo (New York: Atlantic Monthly Press, 2007). This information is based on the author's interviews with a Centra Spike member and with Colonel Hugo Martinez.

15 For more on Hugo Martinez, see Mark Bowden, "Killing the King of Cocaine," The Observer, May 5, 2001, www. theguardian.com/theobserver/2001/may/06/life1.lifemagazine2.

16 Bowden, Killing Pablo.

17 Ibid.

18 Ibid.

19 Ibid.

20 This information is based on the author's personal conversations with a member of Centra Spike.

21 James Brooke, "Cocaine Ring's Latest Campaign: Kidnapping Wealthy Colombians," New York Times, January 7, 1990, www.nytimes.com/1990/01/07/world/cocaine-ring-s-latest-campaign-kidnapping-wealthy-colombians.html.

22 Joseph B. Treaster, "Drug Baron Gives Up in Colombia as End to Extradition Is Approved," New York Times, June 20, 1991, www.nytimes.com/1991/06/20/world/drug-baron-gives-up-in-colombia-as-end-to-extraditionis-approved.html. 


\section{U.S. role in the killing of Pablo Escobar}

23 Ibid.

24 Joseph B. Treaster, "Colombian Drug Baron Escapes Luxurious Prison After Gunfight," New York Times, July 23, 1992, www.nytimes.com/1992/07/23/world/colombian-drug-baron-escapes-luxurious-prison-after-gunfight.html.

25 Ibid.

26 This information is based on the author's personal interviews with Delta personnel; DEA agents Steve Murphy, Javier Pena, and Joe Toth; Hugo Martinez Sr.; and Hugo Martinez, Jr.

27 This information is based on the author's personal interviews with Hugo Martinez and Hugo Martinez Jr.

28 Michael Harris, "Simple Tale of How U.S. Helped Bring Down a Drug King," Los Angeles Times, July 3, 2001, www.latimes.com/archives/la-xpm-2001-jul-03-cl-18006-story.html; Bowden, Killing Pablo.

29 “Drug Cartel Figure Is Slain in Medellin," Associated Press, June 15, 1990, www.nytimes.com/1990/06/15/world/ drug-cartel-figure-is-slain-in-medellin.html.

30 Douglas Farah, "Drug Lord's Base Hurt, Officials Say,” Washington Post, July 15, 1990, www.washingtonpost.com/ archive/politics/1990/07/15/drug-lords-base-hurt-officials-say/46f8e1ac-69ef-45a5-8962-0310a993d403/.

31 Stan Yarbro, "Key Medellin Cartel Figure Killed in Gunfight with Police," Associated Press, August 12, 1990, https://apnews.com/article/ac5fd2d878de4f99b28a0e9b51a308c8.

32 This information is based on the author's personal interviews with members of the Medellin Cartel, as well as from recordings of Escobar's interviews and intercepted (and recorded) phone calls.

33 “Angry Over Blast, Colombia Vigilantes Kill Escobar Lawyer," Los Angeles Times, April 17, 1993, www.latimes. com/archives/la-xpm-1993-04-17-mn-24040-story.html.

34 Bowden, Killing Pablo. The author obtained this cable.

35 Steve Murphy and Javier F. Pena, Manhunters: How We Took Down Pablo Escobar (New York: St. Martin's Press, 2019)

36 Bowden, Killing Pablo.

37 Ibid.

38 “Executive Order 12333 of December 4, 1981 United States Intelligence Activities," Code of Federal Regulations, title 3 (1981): 200 (Washington, DC: National Archives, 1981).

39 This information is based on the author's interviews with Steve Jacoby.

40 This information is based on the author's interviews with Steve Jacoby, Steve Murphy, Javier Pena, Joe Toth, Hugo Martinez Sr., and Hugo Martinez Jr.

41 "Unraveling the Pepes Tangle Web" (Embassy cable to Washington, Bogota: American Embassy Bogata, August 6, 1993), https://nsarchive2.gwu.edu/NSAEBB/NSAEBB243/19930806.pdf.

42 This information is based on the author's interviews with Hugo Martinez Sr. and Hugo Martinez Jr., as well as intercepted (and recorded) phone calls made by Escobar to his family.

43 This information is based on the author's interview with a Delta Force member. 